\title{
Online Teacher Education: Transforming Teachers' Knowledge for Teaching with Digital Technologies
}

\author{
Margaret L. Niess \\ College of Education, Oregon State University, USA \\ niessm@oregonstate.edu
}

\begin{abstract}
This case study focuses teacher education toward the design of online learning educational environments to guide in-service teachers' development of technological pedagogical content knowledge (TPACK), the knowledge for effectively integrating technologies in their classroom instruction. This study describes a researcher-designed learning trajectory instructional approach that highlights key online instructional features that guide teachers in improving and refining their TPACK. In an online Masters' degree program, the research-based learning trajectory transforms teachers' knowledge for teaching mathematics with technologies by focusing on the development of their knowledge-of-practice through "systematic inquiry about teaching" with technology that considers "learners and learning, subject matter and curriculum, and schools and schooling” [27]. The multiple case, descriptive study provides a rich description of how the features of the learning trajectory influence nine K-12 teacher participants' thinking about their own thinking with the technology for learning mathematics and their thinking about their students' thinking and understanding when learning with multiple technologies. The study concludes by proposing that teacher educators consider incorporating such a researcher-designed learning trajectory instructional approach to interweave descriptive tasks with specific pedagogical strategies in order to enhance teachers' knowledge for teaching their content with technology - their TPACK.
\end{abstract}

Keywords: Communities-of-Learners, In-Service Teachers, Learning Trajectory, Knowledge-of-Practice, Online

\section{Introduction}

Tomorrow's learning must engage everyone, in particular the teachers who are now challenged to integrate more and more technologies as learning tools. With the rapid pace of new designs of more robust technologies as learning tools, teachers are at a disadvantage because they have not learned with these newer technologies. Instead, they must examine how these technologies support learning of the content as well as which pedagogical strategies effectively engage students in learning with the technologies. In other words, they must identify, orchestrate, and manage different strategies and learning tasks in their content areas to effectively support students in the $21^{\text {st }}$ century critical learning skills. They must continue learning today in order to guide students in learning for tomorrow. Teacher educators are then challenged to respond to an important question: How can today's teachers engage in learning about the technologies and about teaching with the technologies while they are actively 
teaching in their classrooms?

Teachers' knowledge for teaching for tomorrow is far more than just an understanding of the subject matter content. It ultimately necessitates a robust pedagogical knowledge along with knowledge for teaching with the vast array of technological innovations. The task calls for a reformed view on teachers' knowledge: Technological Pedagogical Content Knowledge [1, 2, 3], otherwise referred to as TPACK [4]. TPACK, as shown in Fig. 1, describes a transformation of teachers' $20^{\text {th }}$ century knowledge at the intersection of content knowledge, pedagogical knowledge and technological knowledge that ultimately supports teachers in strategic thinking of when, where, and how to guide students' learning with technologies.

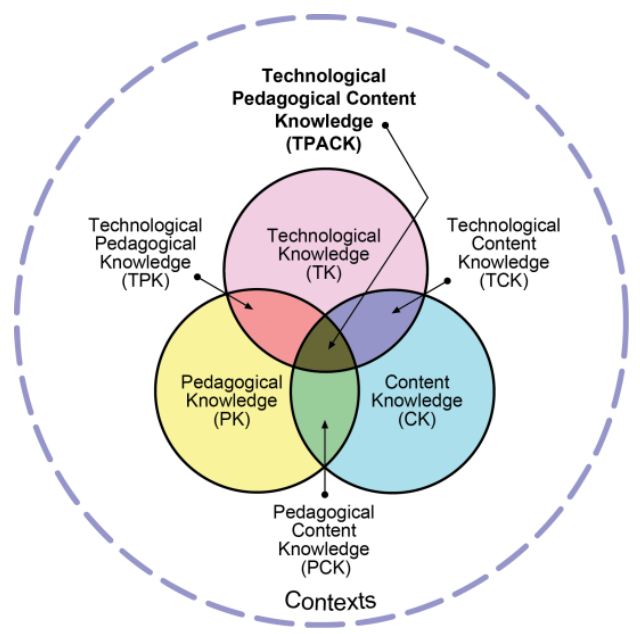

Fig. 1. Representation of Technological Pedagogical Content Knowledge (TPACK) as teachers' transformed knowledge. Reproduced by permission of the publisher, (C) 2012 by tpack.org

While the TPACK construct is recognized and supported by extensive research and scholarly work, teacher educators must design professional in-service learning experiences for transforming teachers' knowledge into a strong pedagogical understanding so they understand and are able to guide their students in collaborating and communicating as they engage in inquiry tasks using multiple technologies as learning tools. When determining appropriate instructional strategies for developing teachers' TPACK, Mishra and Koehler (2006) warn:

There is no single technological solution that applies for every teacher, every course, or for every view of teaching. Quality teaching requires developing a nuanced understanding of the complex relationship, and using this understanding to develop appropriate, context-specific strategies and representations. (p. 1029)

Thus, teacher professional development must guide teachers in relearning, rethinking, and redefining teaching and learning as they know and learned it. Basically, today's teachers must confront their current conceptions for integrating technologies as learning tools in their content areas [5] in order to develop the 
reformed and transformed TPACK understandings.

Among the educational settings for teachers' professional learning experiences, online instructional avenues now provide increased access for teachers who are actively teaching. Teacher educators must design effective online learning experiences for reframing teachers' knowledge. This situation must happen today as the new technologies are evolving at an increasing rate. What are the key features for an online learning trajectory to help teacher educators redesign teachers' learning experiences? What online learning trajectory effectively engages teachers in knowledge-building communities but also provides them with an understanding of the pedagogical challenges for establishing similar communities of learning with technologies in their classrooms? How can teachers gain classroom-based learning experiences where they apply their learning about teaching with technologies?

This case study relied on a researcher-conjectured and empirically supported learning trajectory to enhance in-service teachers' TPACK for teaching with technologies new to them as learning tools. The primary question for this study was: How might a TPACK learning trajectory support a blend of teachers' online communities-of-learners with practical teaching experiences so that they have the opportunity to apply their TPACK in ways that advance their knowledge toward a TPACK-of-practice?

\section{Perspectives}

Reframing in-service teachers' knowledge to reflect the ideas described by TPACK requires systematic inquiries about teaching, learning, subject matter and curriculum, and schooling much as described in Cochran-Smith and Lytle's conception of "knowledge-of-practice" as a "transformed and expanded view of what 'practice' means" (p. 276). This conception assumes that knowledge is "socially constructed by teachers who work together and also by teachers and students as they mingle their pervious experiences, their prior knowledge, their cultural and linguistic resources, and the textual resources and materials of the classroom" (p. 280). This conception of teacher learning necessitates incorporation as an inquiry community where reflection is a central component $[6,5,7]$. This vision is, therefore, referred to as a TPACK-ofpractice.

Learning trajectories are "ordered network of experiences" where students move from "informal ideas, through successive refinements of representation, articulation, and reflection, towards increasingly complex concepts over time" [8]. The online teacher in-service learning trajectory in this study engages the teacher as the student in the instruction designed to move from informal ideas about teaching with technology through successive refinements toward a transformed knowledge for teaching with technology. Purposely, this experience models the instructional strategies for teaching with technologies.

In this study, a researcher-conjectured and empirically supported online learning trajectory [9] guided the instructional strategies using a social metacognitive constructivist instructional framework with essential tools and processes; these features propelled the content development for the online asynchronous, text-based learning professional development. The case study then examined the teachers' 
advancement in their TPACK-of-practice resulting from their experiences in the course that blended teachers' practical experiences with their online community interactions.

\subsection{Tools}

Two significant tools were incorporated in the asynchronous, text-based, online experiences - a community-of-learners and reflection. Previously, learners in online experiences typically have been required to make sense of new information in isolation with only asynchronous avenues for making connections with other learners and the instructor. Now, in through this learning trajectory, an essential tool was a community-of-learners, where the learners communicated and interacted in discussions about the presented tasks and ideas. The intent was to establish the social presence of the learning community such that it functioned as a knowledge-building community.

Multiple researchers have described the importance of a social presence, establishing community member participation and educational experiences that result in meaningful learning, open communication, and group cohesion $[10,11,12,13,14$, 15, 16]. Garrison and Cleveland-Innes (2005) explained the importance of engaging learners in active roles in online environments to support them in building their understanding as they make sense of new information and ideas. A community-oflearners tool provides a dynamic integration of social, cognitive, and teaching presences found to be essential in higher order learning, where they also claim "the reflective and collaborative properties of asynchronous, text-based online learning are well adapted to deep approaches to learning (i.e., cognitive presence)” (p. 145).

The second essential tool in the online learning trajectory was identified as reflection. Critical reflection supported the cognitive presence throughout the online learning trajectory. Learners engaged in reflection were supported in multiple ways, such as preparing content reflective essays as well as reflective essays on the community-of-learners' engagement and providing peer reviews or other learners' work. Also, in this study, the teachers used a TPACK reflective tool for guiding their reflections on their progress with four TPACK components and their emerging TPACK development level [3, 9].

\subsection{Processes}

Another primary component of the online learning trajectory included essential processes when using the tools for learning. These processes engaged the social and cognitive presences in the social metacognitive constructivist framework: shared/individual knowledge development and inquiry. As the learners engaged in the community-of-learners' activities, they shared their understandings of how they interpreted the ideas. As the discussions evolved and their shared understandings became more robust, each learner's individual knowledge was enhanced. With the primary trajectory tools (community-of-learners and reflection) the teacherparticipants moved between group and individual knowledge building where they created understanding that more clearly reflected a worldview with respect to the course content $[17,18,19]$. In other words, their individual knowledge expanded beyond that which they developed independently. 
Another key process with the knowledge-building communities was the use of inquiry-based activities and tasks to support opportunities and experiences where the teacher-participants were engaged in negotiating their understanding of the content. The inquiry process engaged them in constructing their understandings, where they took ownership of their learning, starting with questions and explorations leading to the investigation of worthy questions, issues, problems or ideas. They asked questions, gathered and analyzed information, generated solutions, made decisions, and justified their conclusions. These actions interwove multiple technologies, instructional approaches, and content topics through multiple units. Throughout this process, the teacher-participants consistently engaged in thinking and reflecting about the dynamic interactions among content, pedagogy and technology that emerged as a result of the tasks in their online learning experiences [20,21].

\section{The Program}

The Master's program in Mathematics Education focused on developing teachers' TPACK-of-practice for teaching mathematics with technologies. Four specific courses, as described in Fig. 2, focused on developing their TPACK-of-practice, first by focusing on framing their Technology Knowledge (TK) with Technological Pedagogical Knowledge (TPK), Technological Content Knowledge (TCK), and Pedagogical Content Knowledge (PCK) and second on having them apply this technological knowledge in their teaching practice. The culminating course (SED 594) engaged the in-service teachers in learning and reflecting about their teaching with technologies in multiple ways - academic technology coursework and practical teaching experiences where they implemented and reflected on their ideas and plans.

This fourth course, a blend of online discussions and practical teaching experiences, directed the participants' attention toward examining instructional strategies for teaching with technologies. They concurrently engaged in developing a Scoop portfolio [22], where they designed a five-day sequence of lessons, taught the lessons (reflecting daily and cumulatively on the instruction), and assessed their students' progress in meeting the objectives. The teacher-participants consistently engaged in two reflective thought processes: reflection-in-action and reflection-onaction [23] as they engaged in the practical experiences in this course. They videotaped two lessons where they analyzed and reflected on their instruction and student interaction in the lessons.

As they engaged in this practical experience, they used the online collaborative groups to discuss and explore different instructional strategies, tools, and processes for teaching with technologies. They cooperatively explored and examined reformbased instructional strategies - visible thinking, student discourse, grouping structures, and multiple representations for motivation and engagement. Towards the end of the course, the participants conducted peer reviews of others' Scoop portfolios to improve the communication of the events and thinking. 


\begin{tabular}{|c|c|c|c|}
\hline Perspective & SED 520 & SED 521 & SED 522 \\
\hline $\begin{array}{l}\text { Framing } \\
\text { Technology } \\
\text { Knowledge (TK) } \\
\text { with } \\
\text { Technological } \\
\text { Pedagogical } \\
\text { Knowledge } \\
\text { (TPK), } \\
\text { Technological } \\
\text { Content } \\
\text { Knowledge } \\
\text { (TCK), and } \\
\text { Pedagogical } \\
\text { Content } \\
\text { Knowledge (PCK) }\end{array}$ & $\begin{array}{l}\text { Primary emphasis: } \\
\text { Pedagogical tools } \\
\text { and processes for } \\
\text { learning with } \\
\text { technologies; } \\
\text { learning through } \\
\text { collaboration, } \\
\text { reflection, inquiry, } \\
\text { and } \\
\text { shared/individual } \\
\text { knowledge. } \\
\text { Secondary emphasis: } \\
\text { Multiple multimedia } \\
\text { technologies and } 21^{\text {st }} \\
\text { century literacy in } \\
\text { mathematics }\end{array}$ & $\begin{array}{l}\text { Primary emphasis: } \\
\text { Pedagogical tools } \\
\text { and processes for } \\
\text { learning with } \\
\text { technologies: } \\
\text { learning through } \\
\text { collaboration, } \\
\text { reflection, inquiry } \\
\text { and } \\
\text { shared/individual } \\
\text { knowledge. } \\
\text { Secondary } \\
\text { emphasis: Digital } \\
\text { image and video } \\
\text { technologies for } \\
\text { higher order } \\
\text { thinking in } \\
\text { mathematics. }\end{array}$ & $\begin{array}{l}\text { Primary emphasis: } \\
\text { Spreadsheets as } \\
\text { algebraic reasoning } \\
\text { tools. Secondary } \\
\text { emphasis: } \\
\text { Designing } \\
\text { mathematics } \\
\text { problems for } \\
\text { solution with } \\
\text { dynamic and } \\
\text { dependable } \\
\text { spreadsheets; } \\
\text { designing curricular } \\
\text { units that integrate } \\
\text { the problems. }\end{array}$ \\
\hline $\begin{array}{l}\text { Applying } \\
\text { technology } \\
\text { knowledge in } \\
\text { practice }\end{array}$ & \multicolumn{3}{|c|}{$\begin{array}{l}\text { SED 594 } \\
\text { Primary emphasis: Design, implement, analyze, and reflect on } \\
\text { teaching a technology-infused five-day instruction in mathematics } \\
\text { classroom. Present artifacts in electronic Scoop portfolio. } \\
\text { Secondary emphasis: Instructional strategies, tools and processes } \\
\text { for learning with technologies: explorations through collaboration, } \\
\text { reflection, inquiry, and shared/individual knowledge development. }\end{array}$} \\
\hline $\begin{array}{l}\text { TPACK-of- } \\
\text { Practice }\end{array}$ & & & \\
\hline
\end{tabular}

Fig. 2. Instructional model for developing teachers’ TPACK-of-Practice

\section{The Study}

This descriptive case study examined how the practical teaching experiences blended with teacher-participants' inquiries as a community-of-learners influenced their rethinking, relearning and redefining teaching of mathematics with multiple 
technologies. The course progression engaged them in inquiry about instructional strategies for teaching mathematics with technologies as they simultaneously engaged in systematic inquiry of teaching in their classrooms. The primary research question examined how and in what ways this Scoop inquiry (designing, teaching and analyzing a five-day unit with technology) and the community-of-learners' collaboration influenced the transformation of their TPACK-of-practice.

Nine (9) K-12 in-service teachers (8 females, 1 male; teaching elementary (2), middle school (3) and high school (4)) agreed to participate in the study as they examined their teaching of mathematics with technology in their classrooms. All had taught more than three years, most between 4 and 8 .

\subsection{Data Sources and Evidence}

Individual teacher case binders for each teacher-participant [24] included the Scoop electronic portfolio, the online discussions from the community-of-learners' inquiries, and the final course reflective essays. Independent analysis of the case binders revealed patterns and themes in the discussions and reflections, capturing each teacher's progression and outcomes from the Scoop experiences and the community collaborations. Each analysis documented the teacher-participants' knowledge progression with evidence of their TPACK-of-practice and thinking framed with respect to four TPACK components [3] throughout the practical Scoop tasks and the online collaborative discussions: (1) overarching conceptions about the purposes for incorporating technology in teaching mathematics; (2) knowledge of students' understandings, thinking and learning in mathematics with technology; (3) knowledge of curriculum and curricular materials that integrate technology in learning and teaching mathematics; (4) knowledge of instructional strategies and representations for teaching and learning mathematics with technologies. Collectively, each participant's TPACK-of-practice was described and confirmed. The completed case binders clarified the nine descriptive case analyses while also validating the cross case themes from the Scoop portfolios, online discussions, and the final essays considering this primary research question: What is the impact of the teachers' experiences in the online course that blends the teachers' practical experiences with their online community discussions (orchestrated by the researcher-conjectured learning trajectory) on their TPACK-of-practice?

\section{Results}

Analysis of the nine K-12 mathematics teachers' blended online experiences revealed the development in their TPACK-of-practice. The teacher-participants' experiences and reflections in their practices and discussions described how their TPACK knowledge was influenced. Two representative cases (using pseudonyms) as Teacher 1 (Ms. A) and Teacher 2 (Ms. B) describe the patterns and the diversity of classroom situations. The Scoop blended course influenced the teachers' developing knowledge for teaching mathematics with technologies as revealed by their classroom artifacts, expressions and reflections. This presentation summarizes the transformations in their TPACK-of-practice throughout these experiences. 


\subsection{Teacher: Ms. A}

Through the blended Scoop experiences and online discussions, Ms. A was motivated to implement and examine instructional strategies that were new and different for her typical instruction - working with graphing calculators and using small group work. Her primary instructional mode had consistently been teacher-centered but the Scoop teaching provided an opportunity to test more student-centered instructional strategies. Through her video analyses, she observed that having students working in groups provided opportunities for the students to share ideas; she noted how these opportunities enhanced the students' engagement and learning. "Through the video analysis and my own reflections, I felt I did witness students using discourse.” The variety of opportunities for reflections throughout the blended online course led her to conclude that she wanted to move to more student-centered strategies and she wanted technology to be part of that effort as noted in this comment:

The strategies of grouping, problem solving, questioning, and student

discourse all allow the learning environment to be centered on students who are actively engaged... I want to use more technology centered activities...Technology must be integrated using instructional strategies; on its own, it is not an instructional strategy.

The combination of the online discourse with other teacher-participants as they investigated and discussed the various instructional strategies encouraged Ms. A to try these different instructional strategies as she also implemented technology in her instruction. The entire process resulted in recognition and acceptance of the importance of student-centered strategies and group work. Trying new ideas through this blended course was also seen in the case of Ms. B who wanted to go beyond the technologies to enhance her knowledge beyond those she had previously used with her students.

\subsection{Teacher 2: Ms. B}

Ms. B used the Scoop blended course to integrate multiple technologies for teaching mathematics - technologies that supported communication, collaboration, and inquiry around the mathematical ideas. As she said, "Prior to this year, I have not had much experience with student-centered, hands-on, technology-rich, discovery learning strategies." So in this experience, she added multiple data collection probes to engage students in gathering real data for generating exponential, logarithmic and logistic functions. She recognized that integrating real time data collection with spreadsheets and Google Docs for analysis provided her with an opportunity to conduct a deeper analysis of her instruction as she incorporated multiple different instructional strategies as to what she normally did in her primarily direct instruction classroom strategies. Ms. B was particularly interested in strategies that involved whole group and small group discussions, inquiry learning and real-world applications while taking advantage of the basic features of the multiple technologies. In the videos, she saw how the students "were engaged in discovery learning, brainstorming, technologyenriched lessons, discussion, collaboration, and other strategies." She viewed how they interacted, shared ideas, and provided their understandings of the ideas. This recognition underscored for her the importance of "being a guide rather than the sole provider of information" as she had more typically done. Her community-of-learners' 
discussions supported the implementation of these multiple strategies for more student-directed instruction. In particular she noted that when engaged in discourse, the students were more confident and comfortable communicating their ideas to the class or their small groups. "When they get stuck on a problem, they talk it out and only turn to me for help if they cannot come to a common agreement." Through this process, she recognized that she "learned that they can do more student-centered activities with the right amount of support." She closed with a promise for her future planning: "I will remember this as I plan other lessons."

\subsection{Cross Case Analysis}

These two cases described the major influence of the Scoop blended course through the teachers' classroom actions as they integrated technologies as mathematics learning tools. The research question for this study focused on identifying how and what in this blended course provided access to understanding the teachers' TPACKof-practice. In all nine cases, the teachers recognized the value of incorporating student-centered instruction, an instructional strategy that dominated their online discussions but had not previously dominated their classroom instruction. The Scoop portfolios provided clear descriptions of the classrooms, with pictures of the classrooms and students in action along with presentations and analysis of varying levels of student work. The reflections prior to, during, and following each lesson revealed multiple opportunities for the teachers to think about and learn from their technology-infused lessons. The online discussions became sounding boards for ideas, helping the teachers to think through the ideas, encouraging them to experiment with multiple technologies and instructional strategies as they taught the mathematics they had previously taught in different ways - thus examining their TPACK-of-practice. The cross case analysis for all of the teachers revealed three themes from the blended Scoop process.

1. Throughout the Scoop classroom activities, the teachers were engaged in action research. They examined and discussed various instructional strategies with their online colleagues while they considered how those instructional strategies added to their teaching, supporting student learning. They identified more student-centered discourse and grouping strategies as keys to teaching with technologies, where they guided or facilitated students in higher order thinking with the technologies.

2. Throughout the Scoop blended course, the teachers' reflections consistently caused them to review, rethink, and rephrase their conceptions, connecting their instructional actions with students' successful learning experiences - in essence transforming their knowledge for teaching mathematics with technologies. These reflective actions helped them "think about how to apply the knowledge they received in their experiences for making changes in their instruction" [25].

3. The multiple artifacts gathered through the design and implementation of their instruction with technologies in the Scoop classroom experiences provided the primary support system for their thinking and online discussions. This third theme highlights the importance and value of having access to multiple artifacts as objects to think with [26] as they engaged in the reflective processes. 


\section{Significance and Implications}

As teacher education programs expand to incorporate and take advantage of online learning contexts, teacher educators need to understand how teachers incorporate their thinking about teaching mathematics with technologies into their classroom practice their TPACK-of-practice. The online learning trajectory used in all four of the courses in the Masters program engaged in-service teachers in knowledge-building communities, guiding them in reframing their knowledge for designing studentcentered, problem-based learning with the integration of technologies. The culminating course, the Scoop blended course, revealed specific benefits of such a blending for a teacher education course. Blending the Scoop electronic portfolios (where teachers individually examined their teaching with technologies) with an online community-of-learners collaboration and inquiry about instructional strategies resulted in teachers' enhanced thinking about teaching with technologies. They engaged in (1) action research as they taught with technologies and (2) reflective thinking about their teaching with the technologies where they concurrently (3) used multiple artifacts as objects to think with while developing knowledge for teaching mathematics with technologies. While this study identified one method for incorporating online learning to guide teachers' development of their TPACK-ofpractice, teacher educators need to continue the search for additional ways to guide and support teachers as they teach with technologies, as new and more robust technologies become available for learning tools. The challenge is to incorporate more social metacognitive constructivist features in the online environments to better reflect the more collaborative nature of today's teachers as they continue to build their knowledge for teaching.

\section{References}

1. Angeli, C., \& Valanides, N. (2005). Pre-service teachers as ICT designers: An instructional design model based on an expanded view of pedagogical content knowledge. Journal of Computer-Assisted Learning, 21(4), 292-302.

2. Mishra, P., \& Koehler, M. J. (2006) Technological pedagogical content knowledge: A framework for teacher knowledge. Teachers College Record, 108, 1017-1054.

3. Niess, M. L. (2005). Preparing Teachers to Teach Science and Mathematics With Technology: Developing a Technology Pedagogical Content Knowledge. Teaching and Teacher Education, 21, p. 509-523.

4. Thompson, A. D., \& Mishra, P. (2007). Breaking news: TPCK becomes TPACK! Journal of Computing in Teacher Education, 24(2), 38, 64.

5. Loughran, J. (2002). Effective reflective practice: In search of meaning in learning about teaching. Journal of Teacher Education, 53, 33-43.

6. Cochran-Smith, M., \& Lytle, S. L. Beyond certainty: Taking an inquiry stance on practice. In A. Liberman \& L. Miller (Eds.), Teachers Caught in the Action: Professional Development That Matters. Teachers College Press, New York, NY (2001)

7. Schön. D. A. (1983). The Reflective Practitioner: How Professionals Think In Action. New York, NY: Basic Books.

8. Confrey, J., \& Maloney, A. (2010). The construction, refinement, and early validation of the equipartitioning learning trajectory. Proceedings of the 9th International Conference of the Learning Sciences - Volume 1, 968-975. 
9. Niess, M. L. (2013). Central component descriptors for levels of technological pedagogical content knowledge. Journal of Educational Computing Research, 48(2), 173198.

10. Garrison, D. R., Anderson, T., \& Archer, W. (1999). Critical inquiry in a text-based environment: Computer conferencing in higher education. Internet and Higher Education, 2(2-3), 87-105.

11. Garrison, D. R., \& Cleveland-Innes, M. (2005). Facilitating cognitive presence in online learning: Interaction is not enough. American Journal of Distance Education, 19(3), 133148.

12. Hill, J., Song, L., \& West, R. (2009). Social Learning Theory and Web-Based Learning Environments: A Review of Research and Discussion of Implications. American Journal of Distance Education, 23(2), 88-103.

13. Kinsel, E., Cleveland-Innes, M., \& Garrison, D. R. (2005). Student Role Adjustment in Online Environments: From the Mouths of Online Babes. uwex.edu, 1-5.

14. Rourke, L., Anderson, T., Garrison, D. R., \& Archer, W. (1999). Assessing social presence in asynchronous, text-based computer conferencing. Journal of Distance Education, 14(3), 5170.

15. Sung, E. \& Mayer, R. E. (2012). Five facets of social presence in online distance education. Computers in Human Behavior, 28(5), 1738-1747.

16. Swan, K., \& Shih, L. F. \& Hiltz, S. R. (2006). Assessment and collaboration in online learning. Retrieved from: https://scholar.google.com/scholar?hl=en\&q=Swan\%2C+Shen\%2C+\%26+Hiltz\%2C+200 $6 \& b t n G=\& a s \_s d t=1 \% 2 C 38 \& a s \_s d t p=$

17. Dunlap, J., \& Lowenthal, P. (2014). The power of presence: Our quest for the right mix of social presence in online courses. In A. P. Mizell \& A. A. Pina (Eds.), Real Life Distance Education: Case Studies in Practice. Charlotte, NC: Information Age Publishing.

18. Rienties, B., Tempelaar, D. T., \& Lygo-baker, S. (2013). Redesigning teaching presence in order to enhance cognitive presence, a longitudinal analysis. In Z. Akyol \& D. Garrison (Eds.), Educational Commmunities of Inquiry: Theoretical Framework, Research and Practice (pp. 109-132). Hershey, PA: IGI Global.

19. Swan, K. (2001). Virtual interaction: Design factors affecting student satisfaction and perceived leaning in asychronous online courses. Distance Education, 22(2), 306-331.

20. Roberts, B. (2002). Interaction, reflection and learning at a distance. Open Learning, $17(1)$.

21. Wheatley, G. H. (1992). The role of reflection in mathematics learning. Educational Studies in Mathematics, 23(5), 529-541.

22. Borko, H., Stecher, B., \& Kuffner, K. (2007). Using artifacts to characterize reformoriented instruction: The Scoop Notebook and rating guide. (Technical Report 707). Los Angeles: CA: National Center for Research on Evaluation, Standards, and Student Testing. (ERIC Document Reproduction Service No. ED495853)

23. Schön. D. A. (1983). The Reflective Practitioner: How Professionals Think in Action. New York, NY: Basic Books.

24. Meyers, J. D., Chappell, A., Elder, M., Geist, A., \& Schwidder, L. (2003). Re-integrating the research record. Computing in Science and Engineering, 5(3), 44-50.

25. Dieker, L. A., \& Monda-Amaya, L. E. (1995). Reflective teaching: A process for analyzing journals of preservice educators. Teacher Education and Special Education, 18, 240-252.

26. Papert, S. (2005). You can't think about thinking without thinking about thinking about something. Contemporary Issues in Technology and Teacher Education, 5(3/4), 366-367.

27. Cochran-Smith, M., \& Lytle, S. L. Beyond certainty: Taking an inquiry stance on practice. In A. Liberman \& L. Miller (eds.), Teachers Caught in the Action: Professional Development That Matters. Teachers College Press, New York, NY (2001) 